\title{
PALYNOLOGY AND PALAEO ENVIRONMENT OF THE PATTI FORMATION, SOUTHERN BIDA BASIN, NIGERIA
}

O. F. ADEBAYO

(Received 28 June, 2005; Revision Accepted 18 April, 2006)

\section{ABSTRACT}

Palynological analysis of fifty samples of Ahoko/Ahoko Gbayi sediments in Bida Basin, North Western Nigeria, confirms a Middle to Late Maastrichtian age for the shale interval of Patti Formation. This dating is based mainly on certain well preserved marker angiosperm species such as Monocolpóleniles sp, Monocolpites marginatus, syncolporites substilis and Echitriporites trainguliformis among others. The overwhelming terrestrially derived palynofloras dominated by Palmae and Protecean angiosperms $(96.4 \%)$ are indicative of the predominance of fluviatile environment during the deposition of the dark shale units probably in a restrictive body of water.

\section{KEY wORDS: Formation, Palynomorphs, Prilaeoecology, Palaeoenvironment, Biostratigraphy.}

\section{INTRODUCTION}

The age of Bida Basin has largely been determined by palaeontological evidence (Adeleye and Dessauvagie, 1972; De klazz, 1978; Adeleye, 1979, 1989) while the palynostratigra, hic record of its rock units is fragmentary (Jan du Chene ot al, 1978; Mebradu et al., 1986). The terrestrial to marginal marine origin (Adeyeye, 1989; Braide 1992; Ladipo ol al., 1994) of its sediments prevent independent dating and the general siliciclastic nature of the basin's rocks (predominantly sandstones) which is not suitable for palynomorphs recovery hinders a complete palynological record (Traverse, 1988, Mahmoud, 2003). Salami (1985) even reported that the basin's materials were not found suitable palynologically. However the Patti Formation which contains well exposed carbonaceous shales (among other rock units) at the center of the basin provides a good section for the recovery of palynomorphs.

in the present study angiospermous pollen from the shale unit are abundant, diverse and well preserved. They represent flowering plants that were evolving rapidly and were widely distributed during the deposition, of sediments. These characteristics offer direct and strong biostratigraphic evidence for determining the age and palaeoenvironment of the Patti Formation which is significant for the proper understanding of the geology of the basin. Again the highty diverse nature of the angiospermous assemblage will enrich the basin's palaeofloristic data and provide a means of correlation with other basins within and outside Nigeria.

\section{Geologic setting of the Basin}

Bida Basin is a NW - SE trending depression that is perpendicular to the main axis of the Benue Trough (Fig. 1 and 2). It lies between longitude $4^{\circ} \mathrm{E}$ and $7^{\circ} \mathrm{E}$ and latitutde $7^{\circ} \mathrm{N}$ and $10^{\circ} \mathrm{N}$ and covers an area of $3,500 \mathrm{~km}^{2}$ with about $3 \mathrm{~km}$ thick Upper Cretaceous sedimentary fill in its deepest part (Russ, 1957; Adeleye, 1974; Ojo, 1984; Adeniyi, 1984, 1986). Several authors considered the basin to be a rift bounded tensional structure. This is said to be produced by faulting associated with the Benue Trough and the drifting apart of the African and South American plates consequent to the break-up of these plates in the Late Jurassic to Cretaceous times (Kogbe, "1981; Whiteman, 1982; Ojo and Ajakaiye, 1989). The evolution and development of the basin was attributed to wrench movements associated with the tectonic framework of the Nigerian sedimentary basins (Braide, 1990). Over the years, the basin has been subjected to various geological investigations centred on its stratigraphy and sedimentology (Jones, 1955 ,
1958; Adeleye, 1972, 1973, 1974, 1976; Adeleye and Dessauvagie, 1972; Braide, 1992, Ladipo of al., 1994), hydrogeology (Shekwolo, 1983), biostratigraphy (De Klazz.

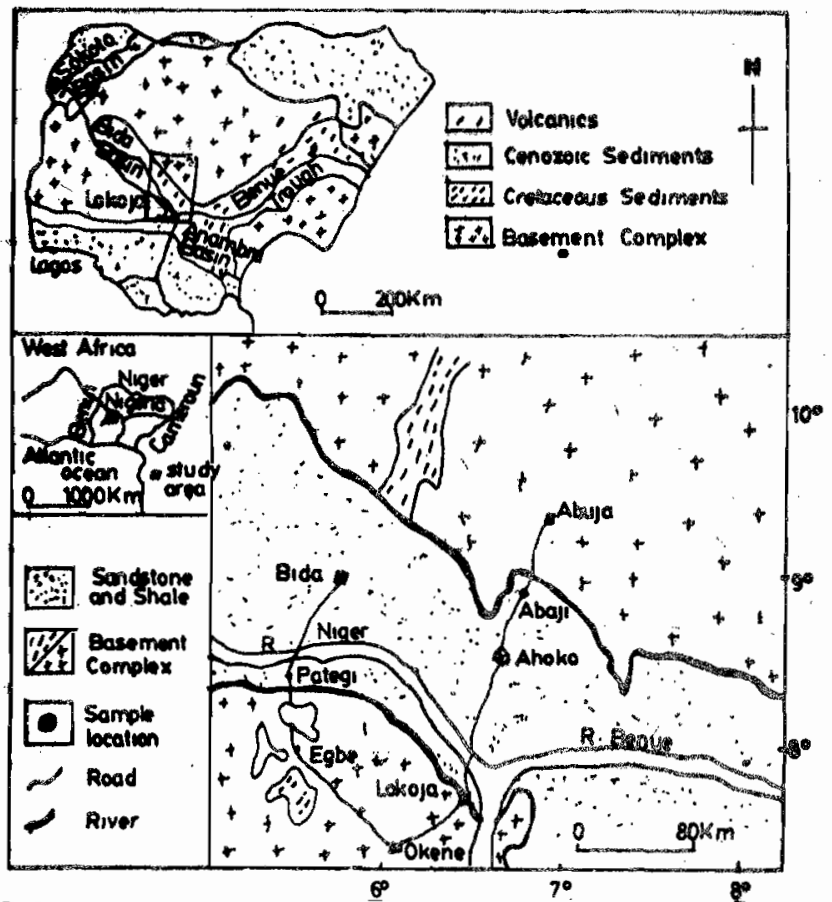

Fin 1 Geological Map of the stuay areal (Acopted tram tan au Chene ef al 1978)

1978; Adeleye, 1979) and hydrocarbon potential (Braide, 1990; Akande and Ojo, 2002).

Four mappable lithostratigraphic units and their lateral equivalents, based on lithologic and depositional characteristics, are recognizable in the two major study. sections (Bida and Lokoja) of the basin. These are the Bida/Lokoja Sandstones, Sakpe Ironstones/Patti Formation, Enagi Siltstones/Patti Formation and Batati/Agbaja Ironstones in ascending order. These lateral equivalents (Fig.2), both within the basins and in the adjoining Anambra Basin represent the continuous depositional phases, from the south to the north and northwest, controlled by the major sea level rise and fall during the Upper Cretaceous time (Berquist, 1971: Douglas et al., 1973).

The abundant oolitic ironstone deposits in the basin equally 


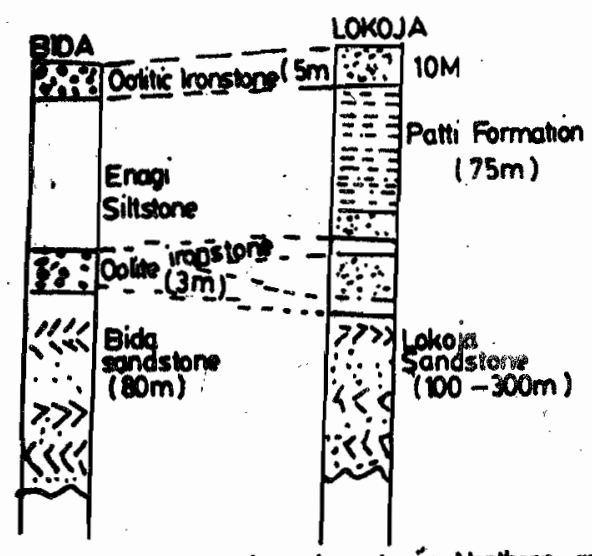

Fin 2a. Cerretation of sediments in Northern and Southern Bids sub-basins (moditied from Adeleve 8Descauvgio 872)

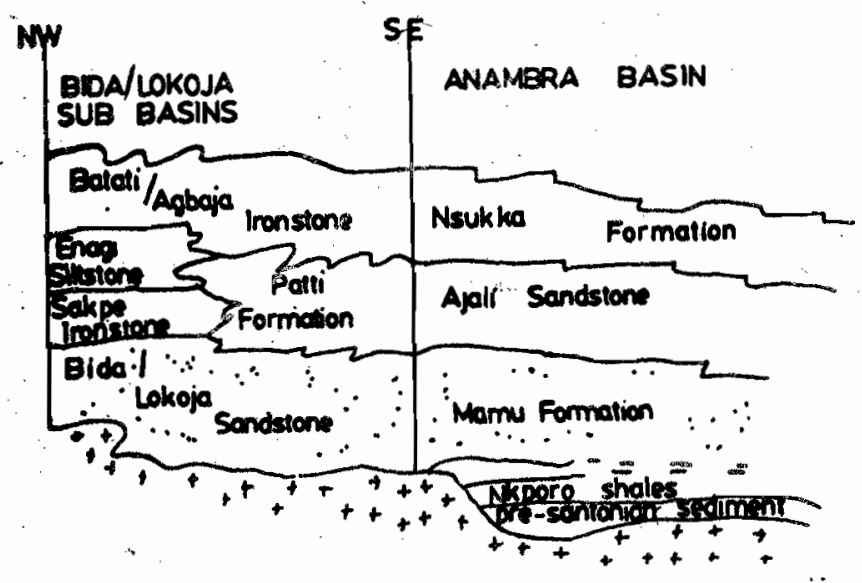

Fin.2b Corralation of Bids Basin to Anambra Basin (After Akande al 2003).

attracted the attention of several researchers (Adeleye, 1973, 1989: Ladipo et al., 1994, Abimbola, 1997).

The depositional environment was said to have $b$.zen dominated by a continental fluvial sedimentation while the presence of intercalated concretional/oolitic ironstones and some arenaceous foraminifera have been ascribed to occasional marine incursion during the rise in sea level (Ojo and Akande, 2003)

\section{MATERIAL AND METHODS}

Stratigraphic sections of Patti Formation located between Ahoko/Ahoko Gbayi along Lokoja - Abaji Road in the central part of the basin were studied. Field data were collected on lithologic characteristics, stratigraphic features and details of sedimentation. Fifty samples were processed using standard palynological procedures. Slides were prepared from unsieved residue using glycerine jelly as mounting medium.

Due to the clastic nature of the sediments, the majority of the processed samples were barren of pálynomorphs. Seven samples contain palynomorphs suitable for the present work. For each sample between 150 and 200 grains were counted and recorded in semi-quantitative term (Table1)

\section{Palynological Assemblage}

Quanlitative data: The noticeable picture presented by the well preserved palynomorphs (plates $1 \& 2$ ) recovered in this study is the dominance of angiospermous pollen. The angiosperms are made up of several species of Echitriporites,
Monocolpollenites, Inaperturotetradites, Psilatricolpiles ano Psiladicolpites. Other important monocolpates such as Arecipites, Longapertites and Retidiporites occur sporadically. The fungal spores and fungal fruiting bodies occur in almost all the samples as minor constituents except in sample 7 where Aseptate fungal spores are noticeably abundant. The

Table 1: Semi-quantitative distribution of Palynomorphs recovered in the Patti Formation Shale.

\begin{tabular}{|c|c|c|c|c|c|c|c|}
\hline Sample No & 1 & 2 & 3 & 4 & 8 & & \\
\hline Angioeperm pollon & & & & & & & \\
\hline Perisyncolportes giganteus Kieserer Jan du Chene 1970 & $\bullet$ & - & $\cdot$ & $\cdot$ & • & & \\
\hline Syncolporites substilis Jandu Chene 1970 & 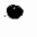 & $\cdot$ & $\cdot$ & - & - & & ? \\
\hline Monocalpollenites ap. & & $\bullet$ & • & $\bullet$ & & & \\
\hline Monocolpites merginatus van Hooken Klinkentbarg 1964 & 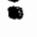 & B & 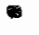 & - & - & & • \\
\hline Constructipovenites ineffectus Klinkenberg 1834 & - & $\cdot$ & $\cdot$ & $\bullet$ & " & & $\cdot$ \\
\hline Pailamonocolpites major & - & - & • & $\cdot$ & $\therefore$ & & - \\
\hline 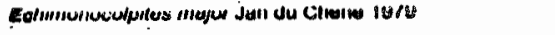 & - & $\cdot$ & $\cdot$ & - & $\cdot$ & & • \\
\hline Lengapentites vanoendenburgi Gommaraed of al. 1868 . & & & • & * & - & & * \\
\hline Prilatricolpites sw. & 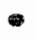 & - & - & - & - & & - \\
\hline Aniledicolpites sp. & 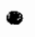 & - & - & $\bullet$ & • & & \\
\hline Rotidiporites sp. & $\cdot$ & & & $\cdot$ & & & • \\
\hline Pailetriporites sp. & - & - & $\cdot$ & ? & - & $\bullet$ & - \\
\hline Eehitriporites triangulifomis van Hooken Klinkenborg 1804 & - & - & - & - & 0 & & • \\
\hline Rotistephanocolpollenites wiltians Gemereat of al. 1988 & - & - & - & 9 & - & & 2 \\
\hline Inaperturotolredites noticulatus Salard Choboldeen 1989 & - & - & - & $\cdot$ & - & & • \\
\hline Arocipites microroticulatus Andareson 10 so & & $\cdot$ & $\because$ & $\cdot$ & ? & & \\
\hline Erocipites pechyoximous Selami 1006 & • & & & * & & & \\
\hline Fungel spores & & & צ & & & & \\
\hline Alueptate fungel upore & - & - & & • & & & - \\
\hline biponicellesponted ap. & $\cdot$ & $"$ & & $\circ$ & & & \\
\hline Oyedoporites ep. & 0 & & • & & & & \\
\hline offer fungal spore: & & & & & $*$ & & \\
\hline Acritarch & & & & & & & \\
\hline Mirchyseridicium brewe Jasomius: & • & $\cdot$ & $\cdot$ & & & & \\
\hline 9oltisphosidium sp. singu Sarjemnt 1974 & - & - & & & & & \\
\hline
\end{tabular}

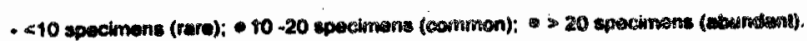

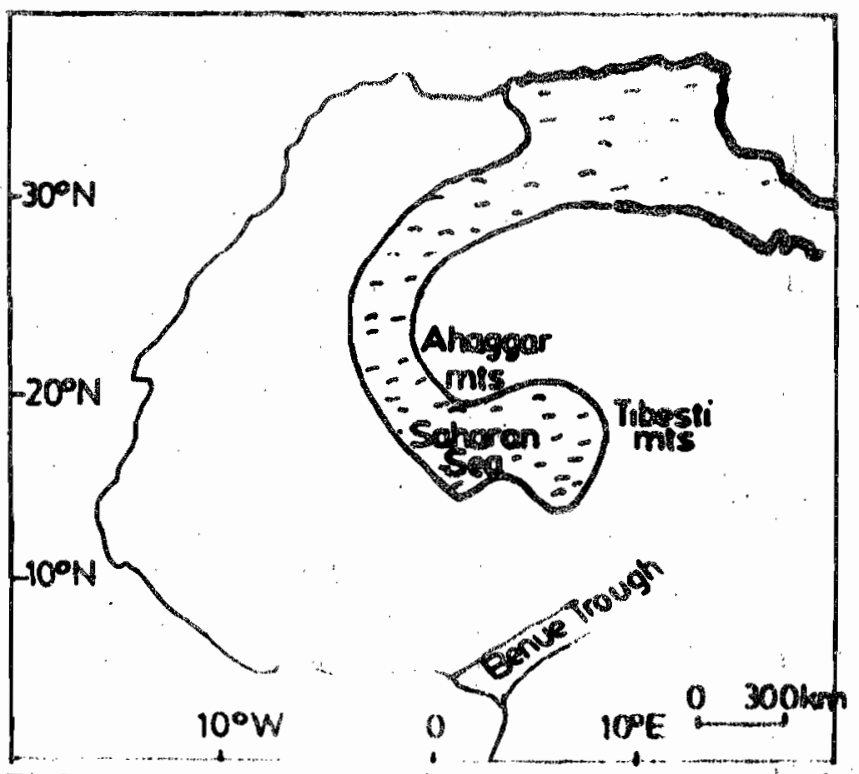

Fig 3. Campanian. Moas trichtian Paleogeagraphy of North and Central West Africa (modified from Kogbe, 1976 and Pelters, 1978 ) 


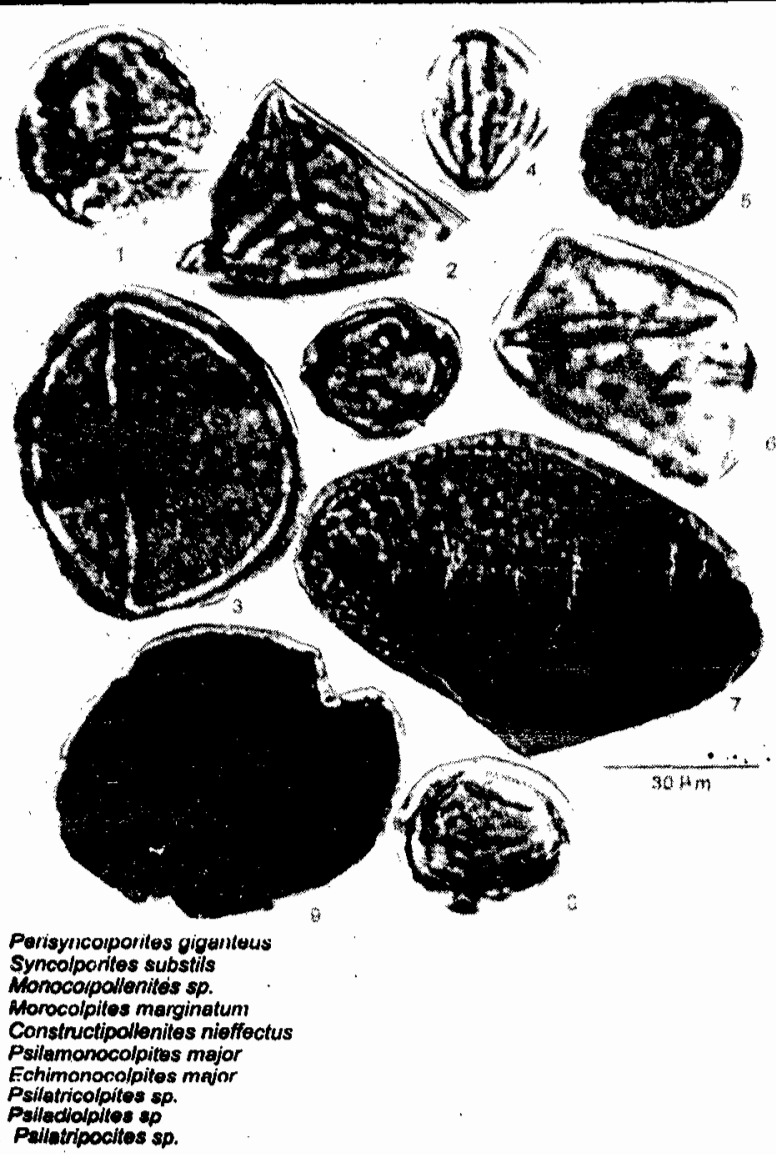

Plate $1 \& 2$

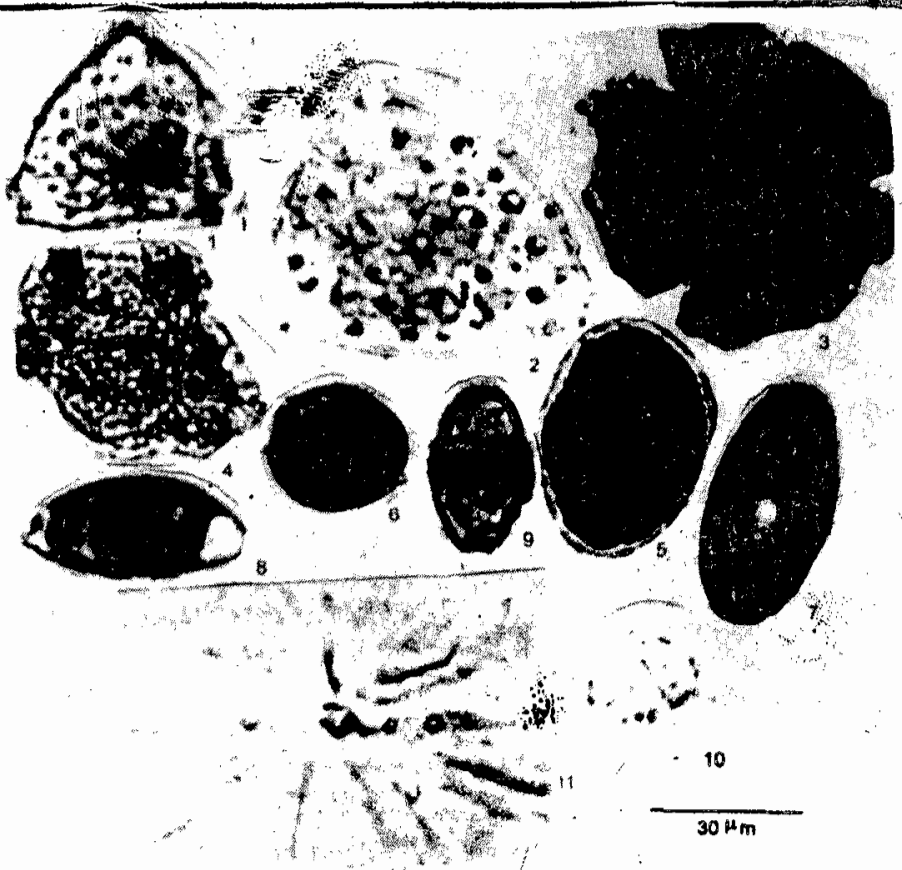

1. Echitnporites trianguliformis

2. Echtriporites

Retistephanocolpollenites williams

. Inaperturotetradites reticulatus

. Arecipiles microreticuletion

. Erecipites pachyexinius

Aseptate fungal spore

9. Dyacloponites sp.

Minchystridium brovo occurrence of minor constituents of microplankton is represented by two species of acritarch, Mirchystridium and Baltisphaeridium, in samples 1 - 3 .

Quantitative data: Generally, the trend of the occurrence of the palynoflorule in the studied samples is s nilar (Table 1, fig. 3). The percentages of angiosperm pollen vary from $76 \%$ to $98 \%$, fungal spores and fungal fruiting from $1 \%$ to $12 \%$ and acritarch from $1 \%$ to $3 \%$. Monocolpates (eg. Monocolpites marginatus and Echimonocolpites major) and triporates (e.g. Echitriporites trainguliformis) are the most abundant, reaching up to $29.6 \%$ and $19 \%$ respectively (fig. 4 ). Longapertites vaneendenburgi, Retidiporites sp. and Arecipites pachyexinous are rare, although they are significant from a stratigraphic point of view. Tricolporates, stephanocolpates and tricolpate psilate forms, which are regular and often high in distribution, constitute other important taxa. For example, Syncolporites substilis varies from $2.7 \%$ in sample 2 to $12 \%$ ir, sample 7 while the percentage of Retistephanocolpollenites williamsi varies from $5 \%$ in sample 2 to $11.5 \%$ in sample 6 .

\section{Biostratigraphy}

Palynological age: Only the relative abundance of stratigraphically significant angiospermous species was used in assigning age to the shale unit of the Patti Formation. This is due to the paucity or age diagnostic organic - walled $r$ 'croplanktons probably because of the terrestrial nature of the formati-n

ic recovered palynomorph assemblage is closely cc.mparable to those of the Maastrichtian interval of coeval irc ical-subtropical Africa, South - America and India (Van Hoen:- Klinkenberg, 1964; Jardine and Magloire, 196; Herngreel. ' "2, 1975 a\&b; Jain, 1975; Jan du Chene et al.,
1978 a\&b; Salard Cheboldaeff, 1981; Baksi and Deb, 1981; Shrank, 1987; Edet and Nyong, 1994; Shrank and Mahmoud. 1998, 2000;' Mahmoud, 2003). The present palynoflora association encompasses several Palmae Palynomorphs that are found in rocks of Maastrichtian age (Herngreen at, 1996; Mahmoud 2003). This is clearly evident fron: the occurrence of Palmae (Monocolpollenites) as well as syncolporates (Syncolporites) and triporates (Echitriponites trainguliformis, Protecean) angiosperms. Contemporary angiospermous palynomorphs of Campanian - Early Maastrichtian ages such as Foveotricolopites giganteus/gigantoreticulatus, Propopylis (Proteacidites) dehaani and spores .(Zlivisporis blanensis and Verrucosisporites sp.)(Jardine and Magloire, 1965; Mahmous, 2 i03) are absent in the present assemblage. The shale unit of the Patti Formation may therefore post - date these moispores. The Upper Maastrichtian assemblage described from southern and northeastern Nigeria (Van Hoeken Klinkenberg, 1964; Jan du Chene, 1977. Lawal and Moullade, 1986; Salami, 1988, Edet and Nyong 1994) contains essentially the same angiospermous elements as recovered in the present study. Again, t e assemblage is comparable to the sequence I! of Jardine and Magloire (1965), the transatlantic Proteacidites dehaani Zone of vermeraad et al.. (1968), Assemblage zone $C$ and L' of Adr hayo and Ojo (2004) as wel as Assemblage zone IV ot Lawal and Moullade dated Upper Maastrichtian. Therefore, in acaution to the Granulatispurites subgranulosus recorded by Mebradu et al. (1986), the presence of well preserved Echitriponites traingulifomis, Monocolpites marginatus, Syncolporites subtilis. Periretisyncolpites giganfeus and Constructipollenites ineffectus further su, ni, and confirm a Middle to Late Maastrichtian age for the Patti Formation shale. 


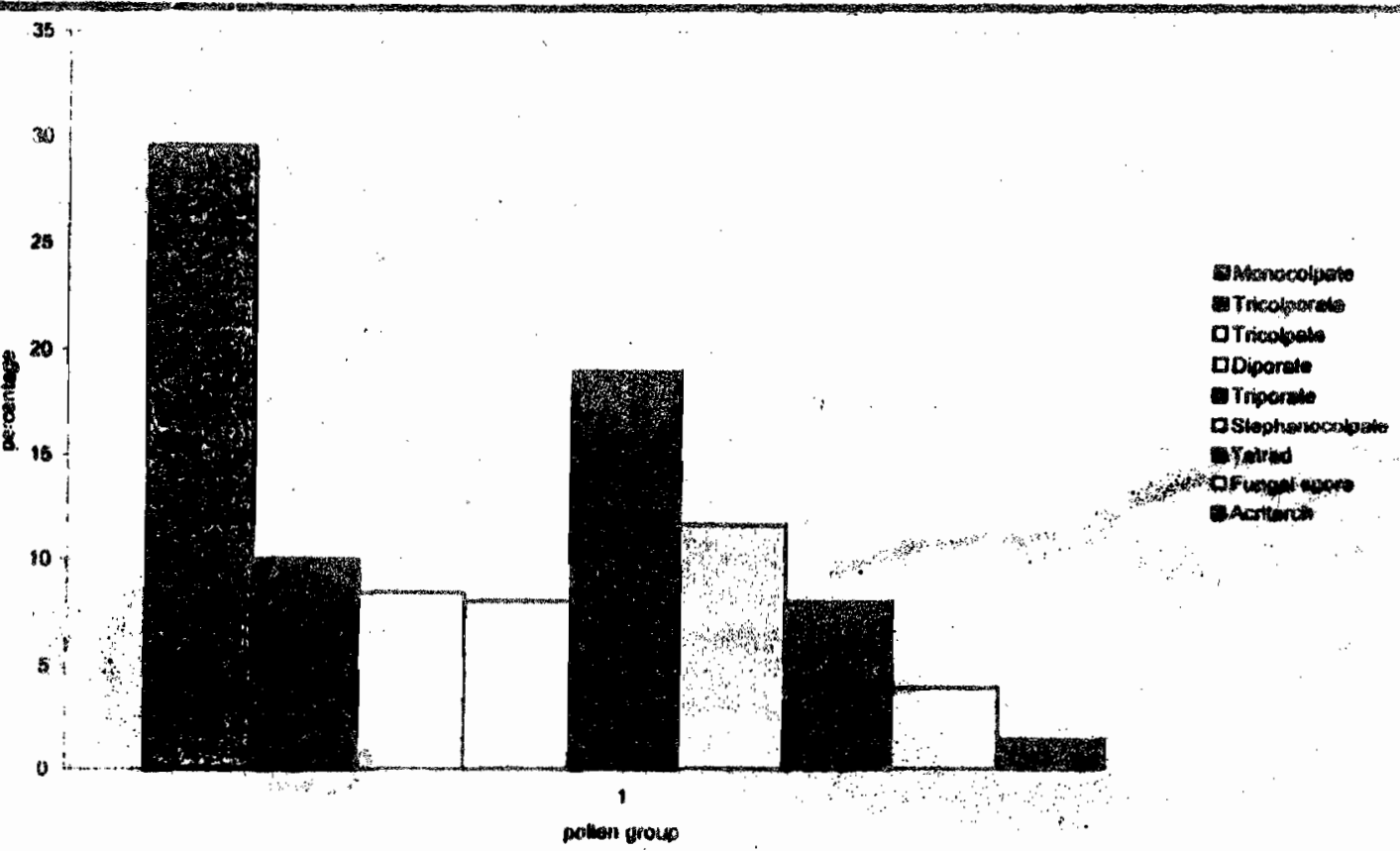

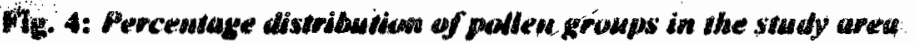

\section{Palacoecological Interpretation}

Palaeocotogical deductions were based on the field data, the bulk composition of the recovered palynomorphs and thair botanical affinities. The dark-light grey, fissile and carbonaceous shale and well laminated siltstones which are interbedded rhythmically by conceretional or massive and troturbated ironstones indicated deposition by suscension setting ive quiet, low energy environment probably in a restricted body of water (Harms et al. 1975; Braide, 1992; Adebayo and Ojo, 2004). However, occasional marginal marine or brackish condition seemed to have existed as shown by the presence of bivalve moulds, few acritarch specimens (Mirchystridium and Baltisphaeridium), pyritised Ammobaculites and Millamina species (in some samples processed separately for foraminifera) and concretional ironstones (Hubert, 1963; Staplin, 1961; Sarjeant, 1974 Norris, 1978). The brakish water must have been brought to the basin through the trans-Saharan seaway (Furon, 1963; Barr, 1972). The northerly connection of the basin with the Tethys Sea was probably via the Sokoto area of the lllumeden Basin during the Campanian-Maastrichtian marine transgression (Kogbe, 1976 and Adeleye, 1979) (Fig.3). The absolute dominance of the palynomorph assemblage by Palmae (Monocolpollenites) and Protecean (Echitriporites) angiasperms (Table 1 ) is indicative of terrestrially derived patyonglora. This view is supported by the abundant woody and plant materials that are land-derived. Thus the prevailing environment during the deposition of Patti Formation shale is fluivialite. The total absence of Nypa-tike mangrove pollen (Spinizonocolpites) and the marine dinocysts equally support a continental setting with relatively dry conditions in the basin during the Maastrichtian (Shrank, 1994, Mahmoud 2003).

\section{CONCLUSION}

The palynofloras of Ahoko IAhoko Gbayi shale section of Patti Formation, Bida Basin, are overwhelmingly of terrestrial origin. They are dominated by angiospermis (Monocolpollenites sp, Monocolpites marginatus, Echitriporites trianguliformis, Retistephanocolpollenites Williamsi). Fungal spore and fruiting bodies and acritarchs (Mirchystifoium and Baltisphaerianum) occur in minor amounts. The age of the formation based mainly on the angiosperm assemblage is Middle to Late Maastrichtian. The Palmae and Protecean pollen association is indicative of terrestrially derived plant materials which are deposited in a predominantly fluviatile environment.

\section{ACKNOWLESGEMENT}

1 wish to acknowledge Messrs Obajimi Felix Usman Mohammed and Adeniyi Eric of the Department Geology, University of Ado Ekiti for their technical assistance. The Palynology Unit, Department of Archaeology University of Ibadan, lbadan provided the facilities for "the photomicrographs.

\section{REFERENCES}

Abimbola, F. A., 1997. Petrographic and paragenetic studies of the Agbaja Ironstone Formation, Nupe Basin, Nigeria. Joumal of African Earth Science. 25: $169-188$.

Adebayo, O. F. and Ojo, A. O., 2004. Palynostratigarphic studies of Cretaceous Deposits of Anambra Basin. Eastern Nigeria. Pakistan Journal of Scientific and Industrial Research, 47(6): 417-422.

Adeleye, D. R., 1972. Stratigraphy and sedimentation of the Upper Cretaceous strata around Bida, Nigeria. Unpublished Ph.D.Thesis University of Ibadan, 1,297.

Adeleye, D. R., 1973. Origin of Ironstone, an example from Middle Niger valley, Nigeria Journal of Sedimentary Petrology. 43: 609-727. 
Adeleye, D. R., 1974. Sediments of the fluvial Bida Sandstone (Cretaceous), Nigeria, Sedimentary Geology; 12: 124.

Adeleye D. R., 1976. Geology of the Middle Niger Valley. In: Kogbe C. A. (ed): Geology of Nigeria, Eizabethan Publ. Co. Lagos, 100-106.

Adeleye, D. R., 1979. A review of Maastrichtian Palaeogeography of the South Illumeden and Nupe basins. Journal of Mining and Geology, 16(2); 199223.

Adaleye D. R. and Dessauvagie T.F.J., 1972. Stratigraphy of the Middle Niger Embayment near Bida, Nigeria. African Geology, University of Ibadan Press, 181 186.

Adeniyi, J. O., 1985. Ground total magnetic intensity of Nupe Basin and the Adjacent Basement Complex, Niger State; Nigerian Journal of Applied Science, 3: 67-68.

Adeniyi, J. C., 1986. Palynomial regional surfaces and twodimensional models in parts of Nupe Basin and the adjacent Basement Complex, Niger State, Nigeria. Nigeria Journal of Applied Science, . 4: 25-34.

Akande, S. O. and Ojo S. B., 2002. Organic petrology and Rock - Eval studies on source rock facies of the Campanian - Maastrichtian Patti Formation, Sourthern Bida Basin, Nigreia. Nigerian Association of Petroleum Exporationists Bulletin. 16(1): 21-39.

Baksi, S. K. and Deb, U., 1981. Palynology of the Upper Cretaceous of the Bengal Basin India. Review of Palaeobotany and Palynology, 31(3/4): 335-365.

Barr,F.T., 1972. Cretaceous biostratigraphy and planktonic foraminifera of Libya. Micropaleontology, 18: 1-46.

Berquist, H. R., 1971. Biogeographical review of Cretaceous foraminifera of Western Hemisphere: in: Yochdson, E. L. (ed): Proceeding North American Papeontologist Convention, 1969, 1565-1609.

Braide, S.P., 1990 Sedimentation and tectonics in the Southern Bida Basin, Nigeria: depositional response to varying tectonic context. American Association of Petroleum Geologist Bulletin. 74 (May, 1990 Convention Issue), 618.

Braide, S. P.; 1992 Geology, Development, Origin and Energy mineral resources potential of the Lokoja Formation in the Southern Bida Basin. Joumal of Mining and Geology. 28 (1): 65-73.

De Klazz, I., 1978. The West African Sedimentary Basins. In: M. Moullade and A.E.M. Nairn (ed): The Phanerozoic Geology of the World II: Mesozoic, A. Elsevier Amsterdam, 371-399.

Douglas, R. G Moullade M. and Nairn, A.E.M., 1973. Causes and consequencies of drift in the South Atlantic: In: Terling, D. H. and Runcorn, S. K. (ed); Implication of Continental Drift to the Earth Sciences, New York Academic Press, 517-537.
Edet, J. J. and Nyong, E. E., 1994. Palynostratigraphy of Nkporo Shale exposures (Late Campanian Maastrichtian) on the Calabar Flank, SE Nigeria. Review of Raiaeobotany and Palynology: 80: 131147

Furon, R., 1963. Geology of Africa: London, Oliver and Boyd, $337 p$.

Germaraad, J. H., Hopping, C. A., Muller J,, 1968. Palynology of Tertiary sediments from Tropical areas. Review of: Palaeobatany and Palynology. 6; 189.348.

Harms, J. C., Southerd, J. C., Spearing, D. R. and Walker, R. G., 1975. Depositional environments interpreted from primary sedimentary structures and stratification sequencies SPEM, Short Course, No 2, Dallas, Texas, 1-161.

Herngreen, G.F.W., 1972. Some new pollen grains from the upper Senonina of Brazil. Pollen Spores, 44 (1): 97 . 112.

Herngreen, G.F.W., 1975a. An Upper Senonian pollen assemblage of borehole 3-PIA-10-AL state of Alagoas, Brazil Pollen Spores, 17 (1): 93-140.

Herngreen G.F.W., 1975b. Palynology of middle and upper Cretaceous strata in Brazil. Meded. Rejks. Gil. Diest. 26(3); 39-91.

Herngreen, G.F.W., Kedves, M., Rovnina, L.V., Smanornova, S.B., 1896. Cretaceous Palynofloral provinces: review. In: Jansonius, J., McGregor, D. C. (eds). Palynology: Principles and Applications, America Association of Stratigraphic Palynologists Foundation 3: 1157-1188.

Hubert, E. M., 1963. The diversity of phytoplankton population in oceanic coastal and estuarine regions. Jour. Mar. Res.' 21 (2); 81-93.

Jain, K. P., 1975. Morphologic reintepretation of some Dinogymnium species with remarks on palaeogeographic and stratigraphic distribution of the genus. Palaeobotanist, 24 (2); 132-139.

Jan du Chene R. E., 1977 Some new pollen species o Upper Maastrichtian Tar Sand, Abeokuta Formation, southern Nigeria. Revista Epanola de Micropaleontologia, 10 (1): 191-201.

Jan du Chene, R. E., Adegoke, O. S., Adeniran, S. A. and Petters, S. W., 1978a. Palynology and Foraminifera of the Lokoja Sandstone (Maastrichtian), Bida Basin, Nigeria. Revista Epanola de Micropaleontologia, 10: 379-393.

Jan du Chene, R. E. De Klazz, I. and Archibong, E. E., 1978 t. Biostratigraphic study of the borehole Ojo-1, S. W. Nigeria with special emphasis on the Cretaceous micorflora. Review of Micropaleotology 21 (3): 123. 129.

Jardine, S. and Magloire, L., 1965. Palynologie et stratigrjie du Cretace des basins du Senegal et de Cote divoire. Memoires Bureau Recherche Geologique at Minieries, 32; 187-245. 
Jones, H. A., 1955. The occurrence of oolitic ironstone in Nigeria, their origin, geological history and petrology. Unpublished D: phil. Thesis, Oxford University, 1-232.

Jones, H. A., 1958. The oolitic ironstone of Agbaja PlateauKabba Province. Records of the Geological Survey of Nigria, 1955-20- 43.

Kogbe, C.A., 1976. Palaeogeographic history of Nigeria from Albian times. In: Kogbe C.A. (ed.): Geology. of Nigeria, Elizabethan Publ. Co. Lagos, 237-252.

Kogbe, C. A., 1981. Geological interpretation of Landsat imageries of part of Central Nigeria. Joumal of Mining and Geology, 18: 66-699.

Ladipo, K. O., Akande, S. O. and Muckear, N. O., 1994. Genesis of oolitic ironstones from the Middle Niger sedimentary basin: Evidence from sedimentological, ore microscopic and geochemcial studies. Joumal of Mining and Geology, 30: 161-, 168.

Lawal, O. and Moullade, . M., 1986. Palynological biostratigraphy of Cretaceous sediments in the upper Benue Basins, NE Nigeria. Review of Micropaleontology, 29 (1): 61-83.

Mahmoud, M. S., 2003. Palynology and palaeonvironment of the Quseir Formation (Campanian) from central Egypt. Joumal of African Earth Sciences, 36: 135148.

Mebradu, S., Imhanobe, J. and Kpandei, L. Z., 1986. Palynostratigraphy of the Ahoko sediments from the Nupe Basin, N. W. Nigeria. Review of Palaeobotany and Palynology, 48: 303-310.

Norris, G., 1978. Phylogeny and a revised suprageneric classification for Triassic - Quaternary organic-walled dinoflagellate cysts (Pyrrhophyta). : Neues Jahrb. fur Geol.und Paleont. 156: 1-30.

Ojo, S, B., 1984. Middle Niger Basin revisited, magnetic constrains on gravity interpretations, Abstract $20^{\text {th }}$ Nigerian Mining and : Geoscience Society Conference. Nsukka Nigreia. 53-53.

Ojo, S. B. and Ajakaye, D. E., 1976. Preliminary interpretation of gravity measurements in the middle Niger Basin Area, Nigeria. In: Kogbe C. A. (ed): Geology of Nigreia. Elizabethan Publ. Co. Lagos, 295-307.

Qjo S. B: and Akande S. O., 2003. Facies relationship and Depositional environment of the upper Cretaceous Lokoja Formation in the Bida Basin. Joumal of Mining and Geology, 39 (1): 39-43.

Russ, W., 1957. The geology of parts of Niger, Zaria and Sokoto Provinces, Geological Survey of Nigeria Bulletin 27.

Salami, M. B., 1985. Upper Senonian and Lower Tertiary pollen grains from the southern Nigeria sedimentary basins. Revista Espanola de Micropaleontologia, 17: 5-26.

Salami, M. B., 1988. Petrography and palynology of Upper Maastrichtian Abeokuta Formation of south western Nigeria. Nigerian Joumal of Science,22 (1/2): 127142.
Salard Cheboldaef, M., 1981. Palynologic Maestrichtien et tertiànaire du Cameroun. Resultants botaniques. Review of Palaeobotany and Pa!ynology, 32 (4): 401 439.

Sarjeant, W.A.S., 1974. English Jurassic dinoflagellate cysts and acritarchs: a re-exaination of some type and figure specimen. Geosci. Man, 15: 1-25.

Shekwolo, P. D., 1990. Hydrogeology of Bida Basin, Nigeria. Ph.D dissertation, Ahmadu Bello University Zaria, Nigeria, Unpublished Thesis. 175p.

Shrank, E., 1987. Biostratigraphic importance of microfloras from the Late Cretaceous clastic series of northwestern Sudan. Cretaceous Research, 8: 29-42.

Shrank, E., 1994. Nonmarine Cretaceous palynology of northern Kordofan, Sudan, with notes on fossil Salviniales (water fern). Geological Rundschau, 83: 773-786.

Shrank, E. and Mahmoud, M. S., 1998. Palynology (pollen, spores and dinoflagellates) and Cretaceous startigraphy of the Dakha Oasis, central Egypt. Joumal of African Earth Sciences, 26 (2): 167-193.

Shrank, E. and Mahmoud, M. S., 2000. New taxa of angiosperm, pollen, miospores and associated palynomorphs from the Early - Late Cretaceous of Egypt (Maghrabi Formation, Kharga Oasis). Review of Palaeobotany and Palynology, 112: 167. 188.

Stapling, f. L., 1961. Reef controlled distribution of Senonian microplankton in Alberta, Canada. Paleontology, 4(3), $392-424$

Traverse, A., 1988. Paleopalynology. Boston, Unwin Hyman, London, Sydney Wellington; 1-600.

Van Hoeken-Klinkenbreg, P.M.J., 1964. A palynological investigation of some Upper Cretaceous sediments in Nigeria. Pollen et Spore, 6(1): 209-231.

Whiteman, A. J., 1982. Nigeria: It's Petroleum Geology, Resources and V Potentials. Graham and Trotman, London,.. I\& II: 1- 394 . 